\title{
ЫЙЫК КУРАНДЫ ОРУС ТИЛИНЕ КОТОРГОН ЭН АЛГАЧКЫ МУСУЛМАН АЯЛ: ИМАН ВАЛЕРИЯ ПОРОХОВА
}

\begin{abstract}
Şohimardan ORUNBEKOV
\section{Аннотация}

Ыйык Кураны Карим түшкөн учурдан баштап эле, адам баласынын көңүлүн өзүнө буруп, жан дүйнөлөрдү эргитип келет. Ыйык Куран араб тилинде түшкөндүктөн анын маанисин түшүнүүдө араб улутундагы элге эч кандай кыйынчылыктар болгон жок. Дүйнөдө эне тили арапча болбогон нечендеген мусулман калкы жашап келет. Алар Ислам динин кабыл алгандан кийин ыйык Китепти түшүнүүдө көптөгөн кыйынчылыктарга туш болушкан. Ошондуктан мусулман калкынын араб тилин үйрөнүүгө кызыктар экендигинин негизги себеби, ыйык Курандын маанисин түп нускасынан үйрөнүҮ болгон. Ал эми араб тилин үйрөнүүгө дарамети жетпеген мусулмандар Курандын маанисин өз тилдеринде которуп берүүчүлөргө муктаж болушкан.

Мурунку аалымдар ыйык Курандын башка тилдерге которулуусуна чечкиндүҮ кадам шилтешкен эмес. Албетте, мунун бир канча себептери бар. Ал эми калкынын саны жагынан көпчүлүгү христиан динин тутунган орус элинин мусулмандар менен болгон алакасы X. кылымдарда башталган. Ыйык Куран жана Ислам дини менен таанышуу XI. кылымдын башында башталганы айтылат. Ыйык Курандын котормосу орус тилинде 1871-жылы алгачкы жолу жарык көргөн. Ошондой эле, түздөн-түз арабчадан которулбастан, батыш тили аркылуу которулган. Акыркы маалыматтарга таянып айта турган болсок ыйык Курандын орус тилиндеги басылып чыккан котормосунун, жалпы саны отузга жакын. Мына ошолордун арасынан ыйык Куранды орус тилине которгон эң алгачкы орус улутундагы мусулман аял; бул- В. Порохова. Биз мына ошол котормочу аял жөнүндө изилдөө жүргүзүүнү максат кылдык. Макалабызда Порохованын өмүр баяны жана анын ыйык Куранды которуу методикасы тууралуу маалымат берүүгө аракеттенебиз.
\end{abstract}

Ачкыч Сөздөр: Ыйык Куран, Котормо, Порохова, Орусча, Маанилери.

\section{KUR'AN-I KERIM'İ RUS DİLINE TERCÜME EDEN ILK MÜSLÜMAN KADIN: İMAN VALERIYYA POROHOVA}

Özet

Kur'an-1 Kerim, ilk nüzulünden itibaren muhataplarının dikkatini cezbedebilmiştir. Kur'an Arapça nazil olduğundan dolayı Araplar Kur'an'1 anlamada herhangi bir sıkıntı çekmemişlerdir. Fakat anadili Arapça olmayanlar İslam'ı din olarak kabul ettiklerinden sonra dilsel ve bağlamsal nedenlerle Kur'an'1 anlamada sıkıntı çekmeye başlamışlardır. İşte bu nedenlerden dolayı Müslümanların Arapça öğrenme isteklerinin Sebepleri de en başta olmak üzere Kur'an'1 anlama gayretidir. Arap dilini öğrenemeyen Müslümanlara gelince onlar kendi dillerinde kutsal Kitabı öğretecek ve tercüme edecek birilerine ihtiyaç duymuşlardır. Önceki âlimler Kur'an'ı tercüme etmekten endişe ederek birkaç sebepten dolayı tercüme etmemişlerdir. Nüfus olarak halkının çoğunluğu Hıristiyan olan Rusların, Müslümanlarla ilk temasları X. Yüzyıla kadar uzanır. Arapça aslından Rus diline kazandırılan ilk meal 1871 yılına aittir. Şu an

\footnotetext{
1 Arş. Gör., Kırgızistan - Türkiye Manas Üniversitesi, İlahiyat Fakültesi, KIRGIZİSTAN, el-mek: orunbek84@gmail.com
} 
Rusçaya tercüme edilen meallerin sayısı otuz civarındadır. Bunların arasında İslam'la şereflenen ilk Müslüman Rus kadının tercümesini bu makalede tanıtmak istiyoruz.

Anahtar kelimeler: Kur'an, Çeviriler, Porohova, Rusça, Meal.

\title{
THE FIRST RUSSIAN MUSLIM WOMAN WHO TRANSLATED THE HOLY QUR'AN INTO RUSSIAN: IMAN VALERIA POROKHOVA
}

\begin{abstract}
From the first revelation the Holy Qur'an, could attract all the attention of interlocutors. Arabs have not suffered any difficulties in the understanding of the Qur'an because it was revealed in their language. However, non-native speakers of Arabic language and some indirect interlocutors who were interested in Islam were suffering in understanding of the Qur'an due to the linguistic and contextual reasons. Muslims are want to learn Arabic because they seek to understand the Qur'an. As for Muslims who could not learn Arabic language, they needed someone to teach and translate the Holy Book in their own language. The previous scholars were worried about translating the Qur'an and did not translate it for a few reasons. It is known that the history of the first contacts of the Russians to Muslims, who have a Christian religion with a majority of the population as a whole, reach to the X.th century. The first Qur'an translation in Russian from Arabic was in 1871. Nowadays the translations, which are currently being translated into Russian, are around thirty. Among these Qur'an translations, we chose Porokhova, who was the first to accept Islam. In this work, we will briefly give information about Porokhova's life, and then we will make some determinations related to her Qur'an translation and method.
\end{abstract}

Key Words: Qur'an, Translations, Porokhova, Russian, Qur'an Translation.

\section{Баш Сөз}

Ыйык Куран акыркы пайгамбардын эң чоң мужизасы жана мусулмандардын жол башчысы. Дүйнөнүн төрт тарабында жашаган мусулман калкы бул ыйык Китептин маанилерин түшүнүүгө ынтызар. Араб тилинде түшүрүлгөн бул ыйык Китеп, Алла Тааланын өкүмдөрүн өз ичине камтыйт. Ар бир мусулман бул өкүмдөрдү аңдап, түшүнүп жана аларды жашоолорунда колдонууга тийиш. Араб эли Куранды түшүнүүдө кыйынчылык көрүшкөн эмес. Анткени, өз тилинде түшкөндүктөн алар үчүн окуп үйрөнүү жана түшүнүү оңой эле иш болгон. Бирок дүйнөдө эне тили арапча болбогон нечендеген мусулман калкы жашап келет. Алар Ислам динин кабыл алгандан кийин ыйык Китепти түшүнүүдө көптөгөн кыйынчылыктарга туш болушкан. Мына ошол күндөн тарта ыйык Курандын маанилерин түшүндүрүү жана түшүнүү жаатында эбегейсиз зор эмгектер жарык көрө баштаган (Atamov, 2013:8). Бул багытта алгач фарс тилине которулганы белгилүY (Aydar, 2014). Ошол кезден учурубузга ыйык Куран көптөгөн тилдерге которулуп келет. Калкынын саны жагынан көпчүлүгү христиан динин тутунган орус элинин мусулмандар менен болгон алакасынын башталгычы X. кылымдарга туура келет. Ыйык Куран жана Ислам дини менен таанышуу XI. кылымдын башында башталганы айтылат. Ыйык Куранды алгач орус тилине которгон инсан И. Голятовский (ө.1688) болгон. Бул котормо алгачкы ирээт жарык көргөнү менен түздөнтүз арабчадан которулбастан, батыш тили аркылуу которулган (Ethem, 2016а: 264). Мындай көрүнүштөрдү Курандын кыргызча котормолорунда да байкоого болот. Кыргызстандагы Курандын котормолоруна тийиштүY иш-аракеттер боюнча, котормо менен алектенгендер аяттардын маанилерин терең түшүнүү үчүн орус тилдүү чыгыш таануучулары тарабынан которулган Курандан пайдаланышкан (Jusupov - Ethem, 2017: 132-157). Мына ушундан улам Кыргызстанда да алгачкы жолу орус тилиндеги 
котормолордон пайдаланылган. Ислам багытындагы китептерди жана ошондой эле Исламдын негизги булагы болгон Куранды, кыргыз тилине которуу аракеттери 1991жылдан тарта күч алган. Алгач Куран түздөн түз араб тилинен эмес, орус тилинен кыргызчага которулган. Албетте бул жаатта ийгиликтерди багындыруу менен бирге максатка жетүү үчүн алгачкы кадамдарда жаңылыштыктар жана кемчиликтер болбой койбойт. Көч бара-бара түзөлөт дегендей, кийинки учурларда ыйык Курандын котормосу орус тилинде да кайрадан түздөлүп, кийинки котормолор түздөн-түз арапчадан которулган (Atamov, 2013:38).

Бул котормолордун белгилүү бир өлчөмдө кемчилиги болсо да, өз доорунда орус элинин ыйык Куранды түшүнүү муктаждыгын камсыз кылып турган. Курандын түздөнтүз араб тилинен котормо иш-аракеттери 1871-жылы башталган. Ыйык Курандын нукура арабчадан орус тилине болгон эң алгачкы котормолору Богославский (ө.1893) жана Саблуков (ө.1880) тарабынан ишке ашкан. Орус тилине которулган Курандын котормолору жөнүндө саналуу гана илимий изилдөөлөрдү көрүүгө болот. Тактап айтканда орус тилиндеги Курандын котормолору Исламий сайттарда гана орун алган. Бул сайттар канчалык маалымат бербесин илимий деңгээлде кадыр баркы таразалана элек. Ал эми Түркияда болсо, орус тилине которулган Курандын котормолоруна көңүл бурула баштаганы байкалат. Акыркы маалыматтар боюнча орус тилине которулган ыйык Курандын маанилери Түркиядагы бир канча докторлук диссертациялар менен макалаларда изилденген. Алардын ичинен проф. док. Шевки Саканын жетекчилиги алдында "Кураны Каримдин орусча котормолорун маниси жана тактыгы жаатында анализдөө" (Kur'an-ı Kerîm'in Rusça Tercümeleri Mana ve Doğruluk Bakımından Değerlendirilmesi) деген темада 2006-жылы Исмайил Шовкхалов докторантура диссертациясын ийгиликтүу жактаган. Изилдөөчү диссертациясында 2006-жылга чейинки которулган Кураны Каримдин орус тилиндеги он төрт котормосун хронологиясын эске алып, изилдеген. Ошондой эле 2006-жылы проф. док. Мехмет Пачажынын жетекчилиги алдында "Игнатый Юлиянович Крачковский жана Иман Валерия Порохованын Куран котормолору” (“Ignatiy Yulianoviç Kraçkovskiy ve İman Valeriya Porohova'nın Rusça Kur'an Tercümeleri”) аттуу темада Саида Саипова диссертациясын жогорку деңгээлде жазып, ийгиликтүү жактаган. (Saipova, 2006) Саида Саипова өзүнүн жигердүҮ эмгегинде изилдөө жүргүзүп, И. Крачковский менен В. Порохованын Куран котормосуна мындайча баа берген: Алардын экөөсү тең ыйык Куранды түзмө-түз арабчадан которушкан. Бирок бул экөөнүн айырмачылыктары И. Крачковский чыгыш таануучусу, ал эми В. Порохованын мусулман аял экендигинде деген. Саида Саипова, бул котормочулар жөнүндө кенен маалымат берип, андан кийин алардын котормолору жөнүндө изилдөө жүргүзгөн.

Бул изилдөөчүлөрдөн айырмаланып, орус тилине которулган ыйык Куранды абдан жогорку деңгээлде изилдеп, котормолордун сапатына салымын кошкон инсандардын бири бул - Мурсел Этхем (Мурсал Атамов) Ал 2013-жылы проф. док. Салих Акдемирдин жетекчилиги алдында "Орус тилинде басылган Кураны Каримдин котормолорун анализдөө”-(Орус тилинде мындан да сапаттуу Курандын которулуусуна салым кошуу) ("Rus Dilinde Yayınlanan Kur'ân-ı Kerim Çevirilerininin Çeviribilim Açısından İncelenmesi” (Başarılı Bir Rusça Kur'an Çevirisinin Oluşturulmasina Katkı)деген темада докторантура диссертациясы жогорку деңгээлде жактаган. Мурсел Этхем бул эмгегинде алгач котормо иштери жөнүндө кенен маалымат берген. Андан кийин орус тилине которулган он төрт котормону изилдеп терең талдоолору менен салымын кошкон. Ошондой эле орус тилине которулган ыйык Курандын котормолорун кыскача таанытуу максатында эки макаланы араб тилинде, ал эми үч макаланы болсо түрк тилинде жазып, бул багытта Түркия мамлекетинин мыкты адиси катары таанылган. Мындан сырткары Курандын орус тилине которулган котормолорун кыскача таанытуу максатында он беттен турган макалалары да жарык көргөн. (Ethem, 2016c: 1071) Ошондой эле, орус тилине которулган Курандын котормолору жөнүндө түздөн-түз байланышы болбосо да, 
Кураны Каримди негиз алган илимий жаатта жазылган диссертация Алау Адилбаевке таандык. Ал бул багыттагы илимий эмгегин ийгиликтүү коргогон (Adilbayev, 2000).

Акыркы маалыматтарга таянып айта турган болсок ыйык Курандын орус тилиндеги басылып чыккан котормосунун, саны жагынан отузга жакын экендиги белгилүү. Мына ошолордун арасынан ыйык Куранды орус тилине которгон эң алгачкы орус улутундагы мусулман аял бул - В. Порохова. Биз ошол аял жана эмгеги жөнүндө маалымат берүүнү максат кылдык.

\section{Иман Валерия Порохованын өмүр баяны.}

Иман Валерия Порохова ыйык Куранды орус тилине которгон жана Ислам динин кабыл алган мусулман аял. Ал, Орусияда жарык дүйнөгө келген жана християн үй бүлөсүндө чоңойгон. Анын чоң атасы Павел Константинович Порохов чоң энеси Александра Леонардова. Атасы Константин Сталиндин репрессиясында курман болгон. Жакындары жөнүндө кенен маалымат жокко эсе. И.В. Порохованын өмүрлүк жары араб улутундагы Мухаммад Саид ар-Рошд болгон. Ал 1975-жылы атайын Сириядан Москвага автомеханика институтуна студент болуп келип, И.В. Порохова менен таанышып калган. Арадан көп өтпөй эле, ошол эле жылы баш кошушуп, 1985-жылы үй-бүлөсү менен Сирияга көчүп кетишкен. Ал жакта ыйык Куранды орус тилине которуу ишин баштап, 1991-жылы аны толук бүтүргөн ( Ethem, 2016а: 269).

\section{Порохованын Куран котормосу жөнүндө}

Валерия Порохованын орус тилине которгон ыйык Курандын котормосунда алгач ага байланыштуу жазылган он жети беттик ырастоолор жана ыраазычылыктардын жазылгандыгы көңүлдү бурат. Котормо иши аяктаган соң, эмгегин ал-Азхар илим изилдөөчү Ислам академиясына жөнөткөн. Ал жерден 1997-жылы басууга уруксат берилген тастыктамалар келген (Ethem, 2016а: 270). Порохова Курандын маанилерин ыр түрүндө которгон. Анын котормосунда сөздөрдүн ички маанисине басым жасалып, мурдагы котормолордун Курандын рухун чагылдырууда жетиштүү маани бербегендиктери айтылат. Мисалы: “Таква” деген сөздү көпчүлүк котормолордо “Аллахтан коркуу” деп которушкан. Чындыгында көңүл бура турган болсок, Курандын бир канча жеринде динине бекем инсан, чыныгы кул жана ыкыластуу пенде деген маанилерге келчү сөздөр гана аны таамай чечмелей алат. Ошондой эле “Сабр” деген сөз да котормолордун барында “сабыр” деп эле которулган. Мына ушундай көрүнүштөрдөн улам Порохова Курандын котормосу жөнүндө сөз кылып, "Кудайдын бир тилде түшүргөн ыйык сөзүн башка тилге которууда өзүндөй кылып которуу мүмкүн эместигине көңүл буруп, котормочунун Ыйык сөздүн маанисин толук ачыктоосу кажет экендигин баса белгилеген.”

Бул котормо жөнүндө эң оор сын пикир айткандардын бири Порохованын ыйык Куранды арабча текстинен түз которбогондугун айткан. Ал эми Крачковскийдин окуучусу Долинина болсо, Порохованын котормосуна изилдөө жүргүзүп, ага мындайча сын пикир айткан: басылып чыккан.

“...Порохованын котормосу абдан начар котормо. Ага карабастан бир канча жолу

...Порохова өзү айткандай эле, бул котормо башкы муфтияттын текшерүүсүнөн өтүп, андан кийин Араб өлкөсүндө басылган. Бирок изилдөөчү кечирим суроо менен Порохованын арабча билбегенин айтып, муну кайсы тилден которгон!? деген суроону тикесинен койгон. Ал чечмелөөдө "Нур" сөзү “Мунир" сөзүнөн келген деп айтып жатса, анда сөз ушул жерден бүттү дегендик деп (башкасына карабай эле койуш керек) өтө оор сөз менен сындаган." (Ethem, 2016a: 270).

Порохованын котормосу түздөн-түз Курандын текстине көз каранды эмес. Эркин которулган десек болот. Котормосун ыр түрүндө которгон Порохова: “Котормолордун 
бирөөсү дагы Курандын адамдарга берген таасириндей таасирди бере албайт. Себеби, башка тилге которулган котормолор Курандын мужизасын, адабий көркөмдүүлүгүн, үн коштоосун жана башка өзгөчөлүктөрүн толук кандуу чагылдыра албайт. Мына ошондуктан орус окуучуларына жан дүйнөнү эргиткен, акыл-ойду багындырган, жүрөктөргө таасирин тийгизген жана сезимдерди ойготкон ыйык Курандын аяттарынын атмосферасын сездирүүнү максат кылдым" деп ыр түрүндө которуу методун тандагандыгын баяндаган (Порохова, 2009: 24). Порохова Шумовскийдей болуп эркин которуу ыкмасын колдонбогон болсо да Куранды которууда максат кылынган тилге ыктаган деп айтсак болчудай (Ethem, 2016b: 198).

Котормо ыр түрүндө жазылгандыктанбы же башка себептерден уламбы, айтор котормодо сөздөрдүн көбү которулбастан андагы болбогон сөздөрдүн ага кошулуп кеткенин байкоого болот. Мисалы Бакара сүрөсүнүн 149- жана150- аяттарын ала турган болсок, эки аяттын да башталышы оп-окшош башталган.

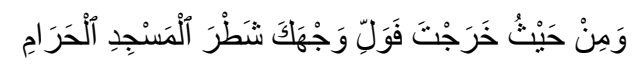

Откуда бы ты ни был родом,

Ты повернись лицом к Запретной (для греха) Мечети...

Кыргызча мааниси мындайча болот:

Мекениң кайсы жер болсо, болсун

Сен жүзүңдү (күнөө иштерди жасоого тыю салынган) Харам Мечитине бургун....

Аятта خَرَج - хаража этишинин сөздүк мааниси “чыгуу”дегенди билдирет, бирок ал бул жерде кыйыр мааниде колдонулган. Аяттын кыргызча мааниси төмөнкүөдөй: “Сен кай тараптан чыксаң да, жүзүңдү Харам Мечити тарапка бур. Адамдардын арасындагы заалымдардан башкалары силерге каршы далил келтире албашы үчүн кайсыл тарапта болсоңор да, жүзүңөрдү ал тарапка бургула....”( Исмаилов, 2006) Ал эми Порохованын бул аятты эмне себептен мындайча которгону түшүнүксүз болууда. Чындыгында Порохованын которгону бул аяттын маанисине дал келбейт. Негизи Порохова ар бир аятты которууда ал аяттын маанисине кошумча ачыктоо берген. Бирок эмнегедир бул аятка түшүндүрмө берген эмес.

Мына ушундай көрүнүштөгү дагы бир мисалды Ниса сүрөсүнүн 103-аятында көрүүге болот.

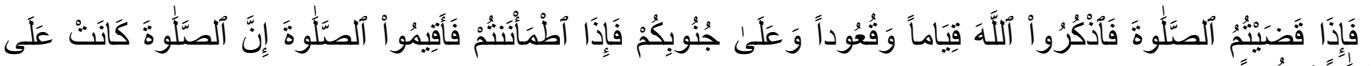

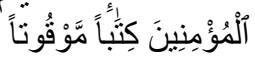

Когда ж пропустите молитву,

(В душе своей) Аллаха призовите,

Стоять ли будете, или сидеть, или лежать.

Когда ж вокруг спокойно станет,

Вы совершите (должную) молитву, -

Молитвы в установленное время

Строго предписаны для верных (Порохова, 2009).

Курандын маанилерин ыр түрүндө которууга аракет кылган Порохова жогоруда мисал катары көрсөтүлгөн аяттын маанисин толук чагылдыра алган эмес. Анткени, тафсир китептеринде жана Түркчө, Кыргызча которулган Куран котормолорунда бул аятты каза намазы (кечиктирилген намаз) деп которушканын көрө албайбыз.

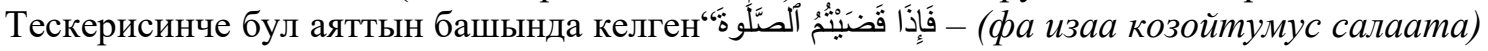


деген мааниси намазды качан окуп бүткөнүңөрдө деп айтылат. Демек Порохова бул жерде чоң жаңылыштык кылган десек болот. Порохованын бул котормосун кыргыз тилине оодара турган болсок, төмөндөгүдөй маани берилип калат.

Намазды каза кылганыңарда, (кечиктирип алганыңарда)

(ичиңерде) Алланы чакыргыла

тургандабы, отургандабы, жаткан абалда болсун.

Качан айлана чөйрө тынчтанганда

Силер айтылган намазды окуйсуңар

Ишенгендерге намаз парз кылынган.

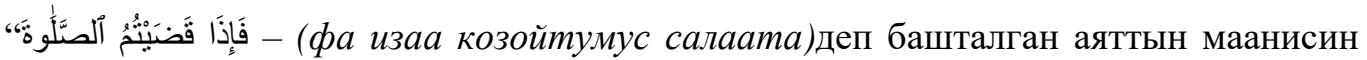
Порохова кечиктирилген намаз деп которууну тандаган. Анын бул маанини тандагандыгынын себеби катарында Абдуллах Йусуф Алиге шилтеме берген. Бирок тафсир китептерин барактаганыбызда Порохованын көз карашына дал келчү жана аны тастыктоочу эч бир маалымат табылган жок.

Порохованын котормосу курандын түздөн-түз текстине көз каранды болбостон, эркин которгондугунан улам андагы бир канча туура эмес маани бергендигин байкоого болот. Мисалы Кадыр сүрөсүнүн алгачкы аяттарына төмөндөгүдөй маани берген:

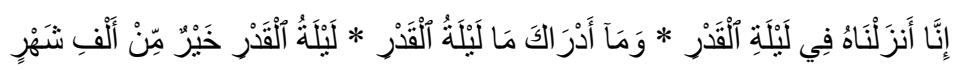

1. Мы повелели снизойти Корану в ночь Аль Кадра.

2. Как изъяснить тебе, что значит "ночь Аль Кадра"?

3. Дороже тысячи (бесплодных) месяцев она!

Биз Куранды Кадыр түн кечесинде түшүүсүн буйрук кылдык.

Сага Кадыр түн кечеси жөнүндө кандайча түшүндүрүү керек?

Ал (пайдасыз) миң айдан да артыгыраак.

Эми ушул аяттарга баштан аяк анализ жүргүзүп көрөлү. Биринчи аятта “' aнbl түшүрдүк”деп өткөн чакта айтылган. Порохова аны буйрук этиштин маанисинде "Мы повелели снизойти - Биз түшүүсүн буйурдук деген мааниде которгон. Экинчи аятта

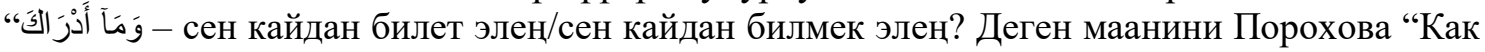
изъяснить тебе - кантип түшүндҮҮрУҮ керек деп которуп, аяттын негизги маанисинен

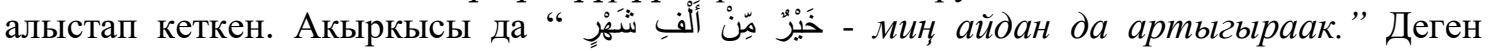
маанини билдирген аятка өзүнүн ачыктоосун кошуп, “Дороже тысячи (бесплодных) месяцев - (пайдасыз) миң айдан да артыгыраак” деп бул жерде да пайдасыз деген сөздү кошуп салган. Бул жерде Порохованын көз карашына караганда Кадыр түн кечесинин миң айдан да артыгыраак болуусу үчүн ошол миң айды ибадатсыз өткөрсө да болот дегендей мааниде которгон. Биздин оюбузда ушундай кошумчалоонун эч кандай кереги жок эле.

Порохова Куранды которууда мурдагы ыйык китептерден абдан көп колдонгон (Порохова, 2009: 22-26). Бул себептен улам мурдагы ыйык китептер эске алынбай которулган котормолорго салыштырмалуу, Порохованын котормосу ийгиликтүү болгон деп айта алабыз (Ethem, 2016с: 1078). Мисал катары Бакара сүрөсүндөгү 2/54.

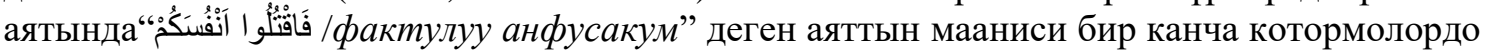
туура эмес мааниде түшүнүлөт. Ал эми Порохова бул аятты мурдагы ыйык китептерден пайдалангандыктан туура которгон. Порохованын котормосу ыр түрүндө которулгандыктан илимий жаатта сөздөргө түшүндүрмө берүү кыйынга турат. Ал ыр 
түрүнде которгондуктан ырдын калыбы бузулбоосу үчүн кээде Курандагы сөздөрдү которбой, кээде Куранда болбогон сөздөрдү кошуп салган.

Көпчүлүк учурда Порхова инверсияланган сүйлөмдөрдү колдонгон. Ар бир аятты өз-өзүнчө которуп, маани берүүгө аракеттенген. Бирок ар бир аят жеке өзүнчө толук сүйлөмдү камтыбай, өзүнөн кийинки аят менен байланышы болгондуктан кээ бир жерлерде сүйлөм толук болбой кемчиликтүү болуп калган.

\section{жыйынтык}

Порохова жана анын котормосу жөнүндө канчалык туура эмес ой пикирлер айтылса да, Россияда эң көп окулган жана сатууга чыгарылган Курандын котормосу деп эсептелет. Бул котормонун түшүндүрмөсү жана формасы орус окуучуларын өзүнө тартуусу жаатында ишеним көрсөтө алган өзгөчө котормо болуп саналат. Порохованын бул котормосуна сын таккандардын көпчүлүгү илимдүүлөр. Тагыраак айтканда карапайым элдин Порохова жана анын котормосу жөнүндө эч кандай арыздануулары байкалбайт. Тескерисинче Порохова бир канча өлкөлөрдө семинарларды берип, эл аралык симпозиумдарга катышып жүргөнү белгилүү.

Адам баласынын акылын өнүктүрүү жаатынан алганда албетте, Порохованын котормосу толук кандуу бир эмгек деп айтууга болбойт. Ошондой болсо да орус эли үчүн ат көтөргүс кызмат кылган десек жаңылышпайбыз. Порохованын эли үчүн жасаган мээнети жерде калбай, орус өкмөтү тарабынан колдоо көрсөтүлүп, расмий түрдө басылып чыгарылуусуна уруксат берилген. Ошондуктан бул жерде баса белгилеп кетчү нерсе, ал өз элинин арасында аброй таап, кадыр баркка ээ болгон. Эң башкысы бул эмгек материялдык себептерден эмес тескерисинче Алла Тааланын акыркы ыйык сөзүн пенделерге жеткирүү максатында жазылган.

\section{Колдонулган адабияттар}

ПОРОХОВА, В. (2009). Коран Перевод Смыслов и Коментарий, Рипол Классик басмаканасы, Москва.

ИСМАИЛОВ, А. (2006) Ыйык Куран маанилеринин кыргызча котормосу. Стамбул. Еркам Басмаканасы.

AYDAR, H. (2014). Kur'ân-1 Kerîm'in Tercümesi Meselesi. İstanbul: Yeni Zamanlar Yayınları.

ATAMOV, M. (2013). Rus Dilinde Yayınlanan Kur'an-l Kerim Çevirilerinin Çeviribilim Açısından İncelenmesi (Başarılı Bir Rusça Kur'an Çevirisinin Oluşturulmasına Katkl). Yayımlanmamış Doktora Tezi, Ankara: Ankara Üniversitesi Sosyal Bilimler Enstitüsü.

SAİPOVA, S. (2006.) İgnatiy Yulianoviç Kraçkovskiy ve Valeriya Porohova'nın Rusça Kur'ân Tercümeleri, Yayımlanmamış Yüksek Lisans Tezi, Ankara: Ankara Üniversitesi Sosyal Bilimler Enstitüsü.

ETHEM, M. (2016a). Rusça Kur'an Çevirilerinin Tanıtımı ve Çeviribilim Açısından İncelenmesi -I (Arapçadan Rusçaya Yapılan Kur'an Çevirileri). Akademik Bakış Dergisi, S. 57, s. 264.

ETHEM, M. (2016b). Rusça Kur'an Çevirilerinin Tanıtımı ve Çeviribilim Açısından İncelenmesi -II (Arapçadan Rusçaya Yapılan Kur'an Çevirileri), International Journal of Culturaland Social Studies (IntJCSS), S. 2, ss. 198-217.

ETHEM, M. (2016c). Rusça Kur'an Çevirilerinin Tanıtımı ve Çeviribilim Açısından İncelenmesi -III (Diğer Dillerden Rusçaya Yapılan Kur'an Çevirileri), Uluslararası Sosyal Araştırmalar Dergisi, S. 47, ss. 1071-1085. 
JUSUPOV, M.; ETHEM, M. (2017). "Ыйык Куран: Маанилеринин Кыргызча Котормосу Менен Аттуу Котормону Таанытуу Жана Илимий Деңгээлде Изилдеп Чыгуу”. Tefsir Araştırmaları Dergisi, Y. 1, S. 1, ss. 132-157.

ALAU, A. (2000). Rus Oryantalistlerin Kur'ân Çalışmaları, Yayımlanmamış Doktora Tezi, Ankara: Ankara Üniversitesi Sosyal Bilimler Enstitüsü.

РЕЗВАН ЭФИМ, А. (2001). Коран и Его Мир, Санк-Петербург.

Erişim Adresi: http://www.islamrf.ru/news/culture/history/12655, числосу: 03/12/2012.

Erişim Adresi: http://www.imanugra.ru/firstep/perevod, числосу: 7/11/2013. 